\title{
QUANTIFICATION OF MINERAL ELEMENTS IN HARDWICKIA BINATA ROXB.-AN ENDEMIC PLANT
}

\author{
SHITAL VALMIKI DESHMUKH*, NAMDEO ANANDRAO GHANAWAT
}

Department of Botany, Yashavantrao Chavan Institute of Science, Satara, Maharashtra, India. Email: coolshitaldeshmukh@gmail.com Received: 25 October 2019, Revised and Accepted: 07 December 2019

\begin{abstract}
Objective: The present study was aimed to investigate the mineral composition of Hardwickia binata Roxb.

Methods: Shade-dried powdered leaves, seed, and husk of $H$. binata were used for mineral analysis. Mineral analysis was carried out by acid digestion method. Potassium, calcium, and sodium were determined using a flame photometer (Thermofisher-FP114), whereas magnesium, zinc, iron, manganese, and copper were estimated using atomic absorption spectrophotometer (Thermofisher-AA203). Remaining elements namely phosphorus, sulfur, and boron were estimated by ultraviolet spectrophotometer and nitrogen by Kjeldahl's apparatus.
\end{abstract}

Results: The total number of 13 mineral elements was found in $H$. binata. In case of values obtained from macroelements, magnesium content was found highest in leaves (51.05\%), followed by husk (20.59\%) and in seed (10.70\%), whereas nitrate content was found lowest in seed (172.33 ppm), followed by leaves (158.17 ppm) and in husk (83.73 ppm). In case of microelements, iron was found maximum in husk (1246.48 ppm), followed by leaves (712.63 ppm) and in seed (157.39 ppm), whereas copper was found minimum in husk (5.73 ppm), followed by seed (4.92 ppm) and in leaves (4.68 ppm).

Conclusion: The present investigation of $H$. binata revealed promising source of magnesium, calcium, iron, and zinc. These elements may serve as nutritional supplement and could be beneficial to the human health as well as livestock to treat against deficiency disorders.

Keywords: Mineral elements, Hardwickia binata, Fabaceae/Caesalpiniaceae.

(C) 2020 The Authors. Published by Innovare Academic Sciences Pvt Ltd. This is an open access article under the CC BY license (http://creativecommons. org/licenses/by/4. 0/) DOI: http://dx.doi.org/10.22159/ajpcr.2020.v13i2.36180

\section{INTRODUCTION}

In plants, primary and secondary metabolites play a vital role in plant growth and development [1]. Phytonutrients are valuable for our body health [2]. The determination of minerals in medicinal plants is potentially useful in nutritional supplement and herbal drug system $[3,4]$. Human body requires organic and inorganic elements for their proper functioning $[5,6]$.

A monotypic genus Hardwickia binata belongs to family Caesalpiniaceae [7]. It is medicinal plant and comes under the endemic biodiversity category [8]. It is multipurpose tree species useful for agroforestry in dryland areas [9]. The tannins from bark of this species are used in medicines for the treatment of diarrhea, worms, indigestion, leprosy, and appetizer [10]. The leaf extracts of $H$. binata showed activity against both Gram-positive and Gram-negative bacteria and fungi. Bioactive substances showed antimicrobial agents including gonorrhea, pneumonia, eye, and mycotic infections [11]. The balsam combined with cubebs and sandal is used for sexually transmitted diseases, leukorrhea, chronic cystitis, and gonorrhea [12]. Leaves are used as cattle fodder and root bark extracts reported anticancer property in H. binata. [13]. Hence, the present study was undertaken to work out mineral analysis of $H$. binata.

\section{METHODS}

Collection, authentication, and preparation of plant material Plant material of $H$. binata was collected from different areas of Maharashtra namely Sangli, Dhule, and Jalgaon districts. The plant material was identified and deposited with voucher specimen (DSV 001) in the Herbarium of Department of Botany, Shivaji University, Kolhapur. The collected materials were shade dried, powdered in a mixer grinder, sieved, and used for analysis.

\section{Mineral analysis}

The mineral analysis was worked out by acid digestion method [14]. Potassium, calcium, and sodium were determined using a flame photometer (Thermofisher-FP114), whereas magnesium, zinc, ferrous, manganese, and copper were estimated using atomic absorption spectrophotometer (Thermofisher-AA203). Remaining elements namely phosphorus, sulfur, and boron were estimated by ultraviolet spectrophotometer, whereas nitrogen by Kjeldahl's apparatus.

\section{RESULTS AND DISCUSSION}

The macro and micro elements in leaves, seed and husk of $H$. binata were estimated and depicted in Table 1. Nitrogen, nitrate, phosphorus, potassium, calcium, magnesium, sulphur and sodium were found to be macroelements while zinc, iron, manganese, copper and boron were microelements.

About all the mineral nutrients, nitrogen is so vital because it is a major component of chlorophyll and amino acids. The nitrogen content was found highest in husk (1.12\%), followed by seed $(0.92 \%)$ and in leaves $(0.84 \%)$. Nitrate serves as an essential plant nutrient helping with tissue development and building the immune system. The concentration of nitrate was observed highest in seed (172.33 ppm), followed by leaves (158.17 ppm) and in husk (83.73 ppm) of H. binata.

Phosphorus is important in the formation of bones and teeth as a cofactor for enzymes [1]. The phosphorus content was determined maximum in leaves $(0.035 \%)$, followed by husk $(0.034 \%)$ and in seed $(0.022 \%)$ of H. binata.

Potassium is important as diuretic, and it takes part in ionic balance of the human body and maintains tissue excitability [6]. It is activator of some enzymes [15]. Previous results of $H$. binata revealed that the 
Table 1: Mineral composition of leaves, seed, and husk of Hardwickia binata Roxb

\begin{tabular}{lllll}
\hline S. No. & Elements & Leaves & Seed & Husk \\
\hline 1. & Nitrogen \% & 0.84 & 0.92 & 1.12 \\
2. & Nitrate ppm & 158.17 & 172.33 & 83.73 \\
3. & Phosphorus \% & 0.035 & 0.022 & 0.034 \\
4. & Potassium \% & 0.021 & 0.044 & 0.095 \\
5. & Calcium \% & 4.42 & 0.17 & 2.99 \\
6. & Magnesium \% & 51.05 & 10.70 & 20.59 \\
7. & Sulfur \% & 0.71 & 0.32 & 0.91 \\
8. & Sodium \% & 1.66 & 2.03 & 1.98 \\
9. & Zinc ppm & 41.59 & 14.78 & 22.52 \\
10. & Ferrous ppm & 712.63 & 157.39 & 1246.48 \\
11. & Manganese ppm & 19.53 & 9.58 & 238.14 \\
12. & Copper ppm & 4.68 & 4.92 & 5.73 \\
13. & Boron ppm & 26.16 & 11.87 & 23.36 \\
\hline
\end{tabular}

leaves were rich in calcium and potassium [7]. In the present study, the concentration of potassium was observed maximum in husk $(0.095 \%)$, followed by seed $(0.044 \%)$ and in leaves $(0.021 \%)$ of $H$. binata.

The maximum amount of calcium was found in leaves (4.42\%), followed by husk $(2.99 \%)$ and in seed $(0.17 \%)$ of $H$. binata. Calcium is an essential nutrient that plays a key role in neuromuscular function and blood clotting, and it gives rigidity to the skeleton and helps to maintain metabolism of the human body $[6,16]$. Excess quantity of calcium ions in the extracellular fluids acts as a mental depressant, and extreme low level of calcium causes spontaneous discharge of nerve fibers, resulting in tetany [6].

In $H$. binata, the highest level of magnesium was observed in leaves (51.05\%), followed by husk (20.59\%) and in seed (10.17\%). Magnesium acts as a cofactor for many enzymes involved in energy metabolism, DNA and RNA synthesis, protein synthesis, and maintenance of electrical potential of nervous tissues and cell membrane $[6,16]$. Increased extracellular concentration of magnesium depresses skeletal muscle contraction, and low level causes increased irritability of the nervous system, peripheral vasodilation, and cardiac arrhythmias [6].

Sulfur is necessary for proper growth and development of living organisms [17]. The concentration of sulfur was estimated highest in husk $(0.91 \%)$, followed by leaves $(0.71 \%)$ and in seed $(0.32 \%)$ of H. binata.

Sodium is essential for the regulation of osmotic pressure of the body and helps to maintain acid-base and water balance of the body. The deficiency of it causes loss of body weight and nerve disorders [18]. Sodium and potassium take part in ionic balance of the human body and maintain tissue excitability because of solubility of salts; Sodium plays an important role in the transport of metabolites. Potassium is of importance as a diuretic [19]. The amount of sodium was estimated maximum in seed $(2.03 \%)$, followed by husk $(1.98 \%)$ and in leaves $(1.66 \%)$ of $H$. binata.

Trace elements content in medicinal plants is very important because some of them play important roles in the formation of active constituents responsible for the remedial properties [20]. Zinc is present in all body tissues and fluids. It is required for a healthy immune system and takes part in the synthesis and degradation of proteins, carbohydrates, lipids, and nucleic acid [16]. The concentration of zinc was observed highest in leaves (41.59 ppm), followed by husk (22.52 ppm) and in seed (14.78\%) of H. binata.

In micronutrient analysis of $H$. binata, iron content was found highest in husk (1246.48 ppm), followed by leaves (712.63 ppm) and in seed (157.39 ppm). The maximum amount of iron in $H$. binata indicates that plant may have high medicinal potential properties against iron deficiency diseases. Iron is a carrier of oxygen from the lungs to tissue by red blood cells, hemoglobin, development of healthy brain, and immune system [16]. Iron deficiency causes anemia [6]. It is important factor in diabetes [18]. The highest percentage of iron and copper content was noticed in the seeds of Bauhinia purpurea [21].

Manganese performs various important functions in humans such as the formation of hemoglobin, growth, and sexual maturation facilitating iron intake and as a cofactor for enzymes. [1]. Previous results revealed that the highest percentage of zinc, lead, and manganese in seeds of $H$. binata, whereas copper was not detected [21]. In the present investigation, the concentration of manganese was estimated maximum in husk (238.14 ppm), followed by leaves (19.53 ppm) and in seed (9.58 ppm) of H. binata.

Copper is an essential trace element and plays a very important role in all living organisms and affects enzyme activity as a cofactor [22]. In H. binata, the amount of copper was found highest in husk (5.73 ppm), followed by seed (4.92 ppm) and in leaves (4.68 ppm).

Boron is non-metal, essential micronutrient. It is responsible for cell wall formation, stabilization, lignifications, and xylem differentiation also essential for cell division and protein synthesis [23]. The concentration of boron was observed maximum in leaves (26.16 ppm), followed by husk (23.36 ppm) and in seed (11.87 ppm) in H. binata.

Overall mineral analysis indicates that in case of macroelements, magnesium content was found highest in leaves $(51.05 \%)$, followed by husk $(20.59 \%)$ and in seed $(10.70 \%)$, whereas nitrate content was found lowest in seed (172.33 ppm), followed by leaves (158.17 ppm) and in husk (83.73 ppm). In case of microelements, iron was observed maximum in husk (1246.48 ppm), followed by leaves (712.63 ppm) and in seed (157.39 ppm), whereas copper content was observed minimum in husk (5.73 ppm), followed by seed (4.92 ppm) and in leaves (4.68 ppm).

\section{CONCLUSION}

The present investigation of $H$. binata revealed promising source of magnesium, calcium, iron, and zinc. These elements may serve as nutritional supplement and could be beneficial to the health of human as well as livestock to treat against deficiency disorders.

\section{ACKNOWLEDGMENTS}

Authors are thankful to principal, Yashavantrao Chavan Institute of Science, Satara, India, for providing the facilities for research work. The authors also thank Head, Department of Botany for their support and cooperation during the research work.

\section{AUTHORS' CONTRIBUTIONS}

All authors have contributed to the completion of this research work.

\section{CONFLICTS OF INTEREST}

The authors declare that there are no conflicts of interest.

\section{REFERENCES}

1. Lalitha ST, Vijayalakshmi K. Proximate composition, nutritional evaluation and mineral analysis in the leaves of indigenous medicinal plant, Alternanthera sessilis. Int J Health Sci Res 2018;8:55-62.

2. Beegum GR, Sugunan VS, Beevy SS. Neutracuetical evaluation of Boerhavia diffusa L. Int J Curr Pharm Res 2017;9:101-4.

3. Talreja T, Sirohi P, Sharma T. Proximate composition analysis of two medicinally important plants Achyranthes aspera and Cissus quadrangularis. Int J Pharm Pharm Sci 2015;7:416-8.

4. Nazri NM, Hazali N, Ibrahim M, Masri M, Ayob MK. Preliminary studies on Acalypha indica: Proximate analysis and phytochemical screening. Int J Pharm Pharm Sci 2016;8:406-8

5. Qotrunnada F, Ade A, Tejaputri NA, Qorina F. Antioxidative activity and phytochemistry profile of Hibiscus sabdariffa herb extracts. Int J Appl Pharm 2019;11:29-32. 
6. Varmani A, Navneet, Prabhat, Chauhan A. Physico-chemical analysis of ash of some medicinal plants growing in Uttarakhand, India. Nature Sci 2010;8:88-91.

7. Seetharam YN, Kotresha K. Foliar venation of some species of Bauhinia L. and Hardwickia binata Roxb. (Caesalpinioideae). Phytomorphology 1998;48:51-9.

8. Vijaya SR, Ravikumar K, Goraya GS. Floristic wealth of Jawadhu hills, Eastern Ghats, with special emphasis on threatened plants. In: Special Habitats and Threatened Plants of India. Vol. 11. Dehradun: Wildlife Institute of India; 2008. p. 187-93.

9. Korwar GR. Hardwickia binate a promising MPTS, for agroforestry in Dryland areas. In: Multipurpose Tree Species for Agroforestry in India. Pune, India: BAIF Development Research Foundation Kamdhenu; 1994. p. 72-5.

10. Ranganathan R, Vijayalakshmi R, Parameswari P. Ethnomedicinal survey of Jawadhu hills in Tamil Nadu. Asian J Pharm Clin Res 2012;5:45-9.

11. Gunaselvi G, Kulasekaren V, Gopal V. Anti bacterial and antifungal activity of various leaves extracts of Hardwickia binata Roxb. (Caesalpinaceae). Int J PharmTech Res 2010;2:2183-7.

12. Khare CP. Indian Medicinal Plants. An Illustrated Dictionary. India: Springer; 2007. p. 302.

13. Prabakaran R, Kumar TS, Rao MV. GC-MS analysis and in vitro cytotoxicity studies of root bark exudates of Hardwickia binata Roxb. Am J Phytomed Clin Ther 2014;2:723-33.

14. Toth SJ, Prince AL, Wallace A, Mikkelsen DS. Rapid quantitative determination of eight mineral elements in plant tissue by a systematic procedure involving use of a flame photometer. Soil Sci 1948;66:459-66.

15. Ponmari M, Balasubiramanian KK. Evaluation of mineral contents in some medicinal plants used by traditional healers. Int J Res Pharm Pharm Sci 2017;2:30-4.

16. Preet R, Gupta RC, Pradhan SK. Elemental analysis and biological studies of Physalis angulata L. using wavelength-dispersive X-ray fluorescence technique, wavelength dispersion X-ray fluorescence, from Rajasthan. Asian J Pharm Clin Res 2017;10:220-4

17. Malgorzata L, Agnieszka S. Recent advances in understanding plant response to sulfur-deficiency stress. Acta Bichim Pol 2008;55:457-71.

18. Prajna PS, Bhat PR. Phytochemical and mineral analysis of root of Loeseneriella arnottiana wight. Int J Curr Biosci Plant Biol 2015;2:67-72

19. Indrayan AK, Sharma S, Durgapal D, Kumar N, Kumar M. Determination of nutritive value and analysis of mineral elements for some medicinally valued plants from Uttaranchal. Curr Sci 2005;89:1252-5.

20. Pattar M, Kerur BR, Nirmala C. Determination of some minerals and trace elements in medicinal plants Acalypha indica (L.), Datura metel (L.) and Tylophora indica used in the treatment of asthama. Eur J Med Plants 2018;22:1-11.

21. Sharanabasappa GK, Santosh MK, Shaila D, Seetharam YN, Sanjeevarao I. Phytochemical studies on Bauhinia racemosa Lam. Bauhinia purpurea Linn. and Hardwickia binata Roxb. E J Chem 2007:4:21-31

22. Hefnawy AE, El-khaiat HM. The importance of copper and the effects of its deficiency and toxicity in animal health. Int $\mathrm{J}$ Livestock Res 2015;5:1-20

23. Chaitanya AK, Pal B, Pati S, Badole S. Role of boron in crop production and its management. Pop Kheti 2014;2:38-41. 